\title{
The spirituality of apocalyptic and millenarian groups. The case of the Branch Davidians in Waco
}

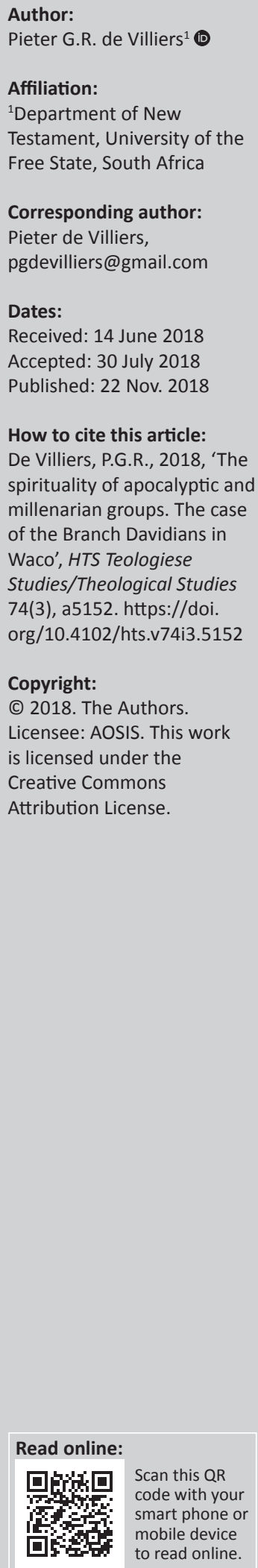

\begin{abstract}
This article investigates the eschatological expectations of apocalyptic and millenarian groups from a spirituality perspective. It first analyses various historical examples of such expectations with particular attention to their sociopolitical consequences. A second part discusses the negative perceptions of, and violent responses to such groups by those who hold them in contempt as lacking spirituality. This issue is then specifically analysed in more detail in terms of the siege of the Davidian group, an offshoot of Adventism, in Waco, Texas, by law enforcement officials in 1993. An analysis of the group's spirituality discusses their religious commitment, spiritual practices and use of the Bible as positive outcomes that they share with other millenarian groups. A concluding part spells out the negative characteristics and dynamics of their spirituality.
\end{abstract}

A critical, generally ignored theme ... is the disposition of governments to misunderstand the difficult ways of millenarian groups, misunderstandings which contributed to gruesome but perhaps avoidable tragedies. ${ }^{1}$

\section{Introduction}

The reception history of apocalyptic texts like Daniel and Revelation reveals the major and sometimes devastating social and political role of the bible on religious groups and society. Throughout the centuries, many apocalyptic groups read apocalyptic texts in the bible literally to predict the imminent end of the world. These groups and their leaders in time mobilised massive audiences to engage in activities that turned out to be destructive and demoralising. In some cases, people gathered in large meetings to wait for the end of the world that was predicted to happen on a specific day. The social consequences were devastating because people stopped working and sold or gave away all their belongings and earthly possessions. There was great disappointment among religious people, and cynicism and mockery among the rest when the predictions did not materialise.

These utopian visions of modern movements were nothing new. Such expectations existed already in Early Christianity, when, for example, prominent theologians in the Latin church interpreted Revelation as a book about the imminent coming of a millennium that would be established in Jerusalem and an elect few (144 000) that would battle with the Antichrist before the final end of the world. They, furthermore, stated that the Antichrist's identity could be deciphered through careful reflection on the number 666, which was the name given to him in Revelation 13:18 (De Villiers 2017: 339-340). They predicted that the end of the world would take place after the Antichrist had been conquered and the evil world replaced by God's new creation (Rev 21-22). The evil world was often associated with the political and religious powers of their own times and thus provoked hostility and even uprisings against these powers. Apprehension of such millenarian expectations was one reason why some faith communities did not include Revelation in their collections of canonical texts.

A few other examples will illustrate how pervasive and consequential the end time expectations of such apocalyptic movements were. The Montanists in 2nd-century Phrygia were originally part of mainstream Christianity that upheld all basic Christian beliefs and tenets. They became known as the New Prophetic Movement because Montanus, their leader, claimed to be a prophet and predicted in one of his ecstatic utterances that the end of the world would happen once the heavenly Jerusalem descended literally on a plain between the towns of Tymion and Pepuze (De Villiers 2017:345). This expectation of the end, like that of the Latin Fathers, was combined with a vilification of the state and their opponents in the mainstream church. The same happened with

1.Rapoport (1996:vii). His added remark refers to specific examples of the radical challenges that millenarian movements pose. 'The terror of the Anabaptists in the sixteenth century drove many governments wild with fury until the Dutch learned how to deal with it'. 
the Donatists in North Africa towards the end of the 4th century who also used apocalyptic texts to predict the imminent end of the world. Their propensity for armed resistance resulted not only in their oppression by the state but also intensified the apprehension of church leaders for apocalyptic texts and groups. This negative attitude was intensified when millenarian groups also claimed martyrdom because of the hard-line actions against them. They interpreted their suffering as a sign of the messianic woes of the end time when the demonic forces would persecute the faithful. This spurred them on to greater militancy, the more so because they thought that this situation meant that their deliverance was imminent (Roman 1996:58). Already at this early stage, the spirituality of these millenarian groups comprised extreme dedication and devotion. Both groups prescribed a strict moral, ascetic lifestyle for their members, especially because of their conviction that only the righteous would inherit the new earth. Both groups studied Scripture meticulously and read it literally. They lead a life of prayer and withdrawal. They were strongly critical of the mainstream church which had, to their mind, become sinful and impure. This nurtured an exclusivist mindset. All in all, then, their millenarian expectations not only affected their social and political standing but also threatened the social stability of the status quo in which they lived. The reading of biblical apocalypses thus had widespread political and social ramifications.

Other examples also show the violent outcomes and major social and political ramifications of an apocalyptic mindset that would contribute to society's negative perception of them. Well known are the tense expectations of the end at crucial moments in the calendar, such as the year 500, the first millennium and, especially also the year 2000. In times close to the year 1000, for example, people joined the first crusade because they expected the end of the world to take place in Jerusalem to where they were marching. Though many were motivated by the prospect of looting, the religious devotion certainly inspired many others. The consequences were immense; thousands died during the ensuing battles. ${ }^{2}$ Another example can be mentioned in a quite different setting. In Bohemia in the 14th century, the Taborites expected an imminent end of the world. Being convinced that prophecies about the Antichrist in biblical texts had been fulfilled, they instigated their followers to join them in killing unbelievers and sinners of their own time as enemies of Christ (Cohn 1970:212). ${ }^{3}$ They were convinced that believers should imitate Christ's rage, cruelty and vengefulness as, they claimed, it was communicated in the end times struggle in Revelation 20-21 (Roman 1996). Kaminsky (2004:338) noted some of the ramifications of this millenarian movement that illuminated how radically society and the church were affected. The groups in Bohemia, like often happens in millenarian settings, turned against their religious peers. They rejected their doctrines, liturgy and rituals. They criticised education of pastors as

\footnotetext{
2.See the extensive historical overview in De Villiers (2017), where the role of calendars in the prediction of end times is investigated and other pertinent examples of millenarian movements are discussed.
}

3.For a discussion of the violent nature of millenarian movements, see Abrams (1984:352). promoting vanity and arrogance. They wanted religious leaders to eschew traditional teachings, to wear inconspicuous clothing and not to shave their heads and beards. This example shows how apocalypses evoked an eschatological fervour characterised by a spirituality that included the use of violence, by a strict moral lifestyle, by opposition to the status quo and by a literal reading of the bible.

Boyer (1993) provides another gory example of the ramifications of millenarian expectations, which he likened to the 20th century group of Branch Davidians in Waco, Texas. This example is especially relevant because it illustrates the role of violence in millenarianism and the vehement responses of authorities to such groups. He describes the uprising organised in 1534 by Jan Bockelson:

a charismatic, theologically obsessed and monomaniacal young tailor who, like David Koresh, anointed himself Messiah, imposed his absolute rule with the aid of a cadre of loyal lieutenants and demanded free sexual access to his female followers. Women who resisted were executed. (Boyer 1993)

Worth quoting in full is Boyer's description of the outcomes of the uprising. Bockelson:

seized control of Münster and proclaimed it as the New Jerusalem, thereby fulfilling the prophecy of Revelation 22. As in Waco, the denouement proved catastrophic. An alliance of alarmed regional princes and the local Catholic bishop raised an army that clamped a tight siege on Münster, bringing on mass starvation and driving Bockelson to ever more brutal excesses. In September 1535, under a promise of safe conduct, the emaciated survivors stumbled from the city, only to face mass slaughter by the besieging forces. Now celebrities, Bockelson and two top aides were paraded around in chains in nearby cities. After torture with red-hot irons, which they endured in stoic silence, the three eventually died. Their corpses, lofted in cages to the top of Münster's church tower, soon fell victim to the ravages of the weather and scavenging birds, but the cages remain to this day, a notable Westphalian tourist attraction. (Boyer 1993)

This phenomenon of end time predictions continued unabatedly after those earlier premodern times. In later times one finds a growing distrust and criticism of apocalyptic and millenarian movements. It is illuminating to see how these movements were also denigrated by associating them with socially disadvantaged people. In the 20th century, the British author D.H. Lawrence famously wrote a scathing attack on such groups in Britain and their interest in the book of Revelation. He denigrated ([1932] 2002:62) them with utter contempt as being popular among the poor and uneducated, naming them as the 'nonconformist chapels, all the Bethels of England and America, and all the Salvation armies'. They were coal miners, 'a Tuesday evening congregation of colliers and colliers' wives, on a black winter night, in the great barnlike Pentecost chapel'. He underlined his classist comment by adding that the book of Revelation was, like the minority groups who read it, driven by hate and jealousy of the privileged, powerful groups in society (Lawrence [1932] 2002:63). 
Lawrence described their apocalyptic thought mindset as typical of social class in various other times and places. The name of the whore (Mystery, Babylon the Great, the mother of harlots and abominations of the earth), 'thrill the old colliers today as they thrilled the Scotch Puritan peasants and the more ferocious of the Christians' (Lawrence [1932] 2002:62). The reading of Revelation by stupid, lower class is 'rampant', in 'all ages down' among 'uneducated people' (Lawrence [1932] 2002:62).

One recognises in this contemptuous description of millenarian groups the type of thought that would persevere in much of contemporary research on apocalyptic thought and of societal attitudes and behaviour to millenarian groups. It comes, therefore, as no surprise that social scientific research would depict these groups in similar negative terms. One of the prominent examples was the social scientific research of Weber who distinguished between churches and sects, with millenarian groups as part of lower classes who reject the privileged elite. ${ }^{4}$

\section{Contempt and violence}

Examples of such negative and bitter opposition to apocalyptic groups can be multiplied. A particularly notorious example is an incident that occurred 25 years ago in the United States that drew the attention of a global audience and that had major social and political consequences for those who were involved. Its outcomes also had implications for religion, churches and theologians that allocated an important and guiding role to the bible for their spiritual life, as is shown by the almost unimaginable publicity it received. Pedrotti (2011) notes:

The Waco standoff and the subsequent tragedy made a significant impact upon American culture. The persistent conviction that the climactic fire on April 19th was not an accident or an act of religious suicide, but was instead set by agents of the United States government, has permeated American right-wing extremist culture, fueling conspiracy theories and antigovernment rhetoric. (p. 7)

In 1993 a group of 80 law enforcement officers stormed the property of a then obscure millennial group that was known as the Branch Davidians near Waco in Texas - in a place that carried the name of the biblical Mount Carmel. This invasion is to be understood within the history of the group and their reputation among people in their home town of Waco. The Branch Davidians were to some extent the outcome of a long millenarian tradition, specifically in the Davidian tradition, but more generally within the Adventist discourse. The group belonged to an ecclesiastical tradition that was known for its apocalyptic mindset and for its controversial history. This group was, namely, an offshoot of the Seventh Day Adventists ${ }^{5}$ with its long prehistory of millennial expectations, such as the Great Disappointment in 1843 when thousands of

4.One recognises the influence of such interpretations also in biblical studies as discipline. Cook (1995:7) discusses how Plöger and Vielhauer distinguished between eschatological groups that existed as secret conventicles over against the theocratic, powerful groups.

5.See the important article of Gladwell (2014), https://www.newyorker.com/ magazine/2014/03/31/sacred-and-profane- 4 and also the illuminating discussion with Jane Docherty on https://www.beyondintractability.org/audiodisplay/docherty-j. followers of William Miller gathered in several places in north-east United States, to await the end of the world as predicted by Miller, their leader. ${ }^{6}$ The Seventh Day Adventist church originated after this event when a couple of followers explained the wrong prediction as a result of the failure of the believers to observe the Sabbath as day of rest. In the following years, some groups broke away from the church, among which was also the Davidians in Waco (Dick 1986).

The leaders of the Davidian Seventh Day Adventists (from which the Branch Davidians would break away later on) also prophesied about the end time during the first 60 years of their existence in Waco. They claimed special authority as prophets to interpret biblical texts as revelations about the end of the world. The first leader of the Davidian group was Victor Houteff, who bought Mount Carmel and established the group there. He was convinced that the imminent Kingdom of God, mirroring the biblical King David's kingdom, would be established there. From an early stage, therefore, the group valued the notion of a Davidic kingdom, explaining why they became known as Davidians and illuminating the name that David Koresh later on chose for himself. The central role of biblical texts and of prophetic activities is illustrated when Hoeteff's widow, Florence, who lead the group after his death, predicted that Victor, her late husband, would be raised from the dead when the end of the world would take place at Passover on 22 April 1959 at Mount Carmel. She based her prediction on the 42 months mentioned in Revelation 11:3 and 12:6. ${ }^{7}$ The political and social implications of such an apocalyptic mindset are further illustrated by her prediction that the end would happen during a war in the Middle East, but also by the gathering of large crowds in Waco to listen to her exposition and to be prepared for the event. When her prophecy failed to realise, most left Mount Carmel for good, many of them contemptuously accusing Florence as being a false prophet (Bianchi 2005:20).

Through the next couple of decades, there were a number of power struggles and sometimes deadly infighting among the leaders. The Branch Davidians split from the Davidian group in 1955 under the leadership of Benjamin Roden and his wife, Lois, who became the president after Benjamin's death. Their son, George Roden, for example, expelled David Koresh who was at that stage a member of the group, got involved in a gun fight with him, killed another member of the group with an axe and was submitted to a psychiatric hospital. In the period before the invasion by the Federal Bureau of Investigation (FBI) in 1993, some members of the community reported to the local media Koresh's abusive behaviour towards children, whilst rumours began circulating that group members were stockpiling firearms (Pedrotti 2011:6). The authorities began to take an interest in the group's activities. In response to these reports, the national anti-cult organisations such as the Cult Awareness Network (CAN)

6.See Landes (2003) for a discussion of other millenarians like the Millerites, Russelites, Darby, Scofield and, in the 20th century, John Walvoord, Charles Ryrie, Hal Lindsey, Tim LaHaye and Joel Rosenberg.

7.See the discussion in Newport (2017). 
became involved. They inflamed the situation and prejudiced the community by naming the Davidians a cult. Pedrotti (2011:7) spells out the negative political and social impact of this involvement by noting how institutions like the CAN make 'their living by rescuing and "deprogramming" those who have been caught in the clutches of a sinister cult' (Pedrotti 2011:7). This prehistory of the Mount Carmel group with its many conflicts, deadly strife, court cases and their moral lifestyle did nothing to enhance their reputation among the surrounding communities. The situation was also not managed with the necessary insight and wisdom when authorities and activists labelled them with names that could only intensify existing prejudices against them.

The group would become especially notorious after the authorities, seeking to apprehend David Koresh, leader of the Branch Davidians and some other members who were under suspicion for being in possession of illegal arms, invaded the compound. The invasion had an extremely violent nature. ${ }^{8}$ In an initial attack on the 19 April 1993, 10 people were killed and 20 wounded. Then followed a long-drawn-out siege for 51 days which ended when the property was invaded with heavily armoured vehicles, the buildings were gassed and set alight by government agents. Ultimately 76 of the 92 members of the religious group burned to death in the fire. The siege was widely reported by the media and watched by a global television audience. Television sets relayed day after day to homes across the globe how the siege developed and what attempts were made to get the community to surrender to the authorities. During this time all the prejudices against the groups were repeated in media comments about the situation.

The extremely violent handling of the matter reflects strong prejudices towards and long-standing antagonism against millenarian apocalyptic groups. ${ }^{9}$ There was no indication that the authorities tried to understand the group or fathom the nature of their spirituality, nor were specialists in millennial groups taken seriously when they tried to provide input to defuse the situation. The underlying dynamics revealed the two very different worlds that were on a collision course during the long siege. Transcripts of their communication with the group to bring about an end to the siege reveal nothing but contempt for them. ${ }^{10}$

This particular incident fits into a larger picture. Psychological, social and political arguments are often used to describe millennial movements as dangerous, asocial and violent cults and their adherents as naïve, exploited people. As a result of this long history of prejudice against millenarian movements, the authorities in Waco were, like religious persons and the public

8.The Federal Bureau of Investigation attacked the compound with an extraordinary strong military force, including 12 tanks, four combat-engineering vehicles and 890 officers. See Gladwell (2014) for the composition of this attacking force.

9.For an extensive discussion, see Tabor and Gallagher (1995). For Tabor's recent reflection on these events, see his blog: https://jamestabor.com/april-19-1993waco-branch-davidian-tragedy-going-on-25-years/ (April 2017; viewed 01 March 2018).

10.Such convictions help explain the remarks in transcripts of the negotiations of the invaders that indicate the desire to free members from what was said to be thei captivity and from Koresh's abuse. in general, apprehensive of any movement that is involved in speculations of the future and the end of the world. In the words of Pedrotti (2011:1), 'Over the course of the standoff, the Branch Davidians became known as a doomsday suicide cult associated with militant gun violence, sexual perversion, child abuse, brainwashing and religious deviance'. ${ }^{11}$ There is an aversion, even among many religious people, to groups that await a future that will comprise the resurrection of the dead and a new heaven and earth. Such expectations are regarded as premodern, escapist and non-rational. In some indirect ways.

Like often happened throughout history, such communities were seen as people with mental issues, exploited by a deranged leader, who, especially in the case of Koresh, had an obscene, immoral lifestyle that contravenes all good social conventions. Prominent in the criticism of the Branch Davidians, for example, was that Koresh took some 20 women, some as young as 12 years old, as his wives and fathered several children with them. He also prescribed celibacy to the men, some of whom were married or related to Koresh's wives, and gave them single rooms in a separate location where they had no contact with them. For many this was an indication of a psychopathic nature and an abuse of power over those who lived with him in the compound. These followers were regarded as having been brainwashed and deceived by a cunning manipulator (Doyle 2012:10).

\section{The religious roots and commitments}

In the glare of the media attention to the more sensational aspects of the siege and its outcomes, less attention has been given to the religious concerns, beliefs and dynamics that characterise their existence as a faith community or to their spiritual conduct. Such matters are obfuscated by the extraordinary and sensational events that get reported. The terrible events during the invasion created the context within which the group was judged and their story was told. The attention was on their mistakes, their scandals, their reputation and their eschatological preoccupation. As a result, the underlying spirituality of the group tends to be overlooked. Like with all apocalyptic groups, there is, however, a much more complex story to be told, as will be explained now.

\section{Ecclesiastical tradition}

Though the Branch Davidians comprised a small number of followers, they stem from the Seventh Day Adventists, a tradition that is now an established presence in mainstream Christianity. The Seventh Day Adventists share central beliefs of mainstream Christianity. It is a part of the Christian Protestant tradition, not only in the United States but

11.For an extensive discussion of publications on the Davidians, see Bianchi (2005) See also his remark (2011): Immediately following the fire, quickly written popular works describing the Branch Davidians and the standoff at the Mount Carmel Center began to appear. These works tend to support the already dominant media narrative of brainwashing, cult behavior and mass suicide (p. 4). And Thibodeau (1999) writes: ... the government spin doctors have put an evil slant on ou character, casting us as child abusers, drug users, gun nuts, demonizing ou community as a bunch of Bible-crazed loonies. They claim the women and children living here are hostages. This blatant deceit is a rotten strategy, and I have a
stubbornly naive faith that the FBI will not be allowed to get away with it' (p. ix). 
also globally. ${ }^{12}$ Originally, as was indicated above, they were especially vilified and mocked after the disastrous events of 1843 when the expected end of the world did not materialise. Their history reveals how they outgrew that difficult time. In this regard, they display typical features of movements that survive the negativities of their origins, but also of groups that eventually energise the church. Examples in case are not only the low church tradition in the United Kingdom but also peace church traditions like the Quakers.

Boyer (1993) notes how such innovative movements 'attracted ridicule that often masked fears of anarchy and disorder'. This remark reflects the negative nature of the hateful prejudices and actions against such new and unorthodox groups. He refers as example to the reputation of groups that were criticised by their contemporaries as disruptive sectarians of dubious moral character:

The Disciples of Christ (Campbellite) church, arising amid the fervor of frontier revivals, was caricatured as a collection of wild ranters and weeping enthusiasts. Not only the Seventh-Day Adventists but also Joseph Smith's Mormon followers, John Humphrey Noyes's Perfectionists, Ann Lee's Shakers and, later, Charles Taze Russell's Jehovah's Witnesses and Mary Baker Eddy's Christian Scientists were all denounced as dangerous radicals and a grave threat to orthodoxy and social order. Much of the same language that we now hear aimed at Koresh was aimed at what now rank as some of the most respected denominations in America. ${ }^{13}$

One gets a completely different impression in light of serious research on these groups. Some theologians explained the dynamical growth of such apocalyptic groups in terms of their creative power and innovation. Among them was Niebuhr, ${ }^{14}$ who noted that such groups criticised the established faith communities, often because of their lack of solidarity with the poor and the marginalised in their midst. Other than Lawrence who ascribed this critical attitude to a vindictive jealousy of the status quo, it is argued that their criticism was steered and determined by their spirituality with its keen sense of social justice. One could add that these groups often authenticated their faith commitments with an impressive ethical, sober lifestyle and with an admirable service to the poor. ${ }^{15}$

It is striking that the changing appreciation and fate of millenarian groups are also to be found in an academic context. For a long time, researchers regarded these groups as an aberration and a fringe phenomenon because they were seen as escapist movements obsessed by visionary and ecstatic

12.See the website of the church (https://www.adventist.org/en/beliefs/) that states Currently, Adventists hold 28 fundamental beliefs that can be organized into six categories - the doctrines of God, man, salvation, the church, the Christian life and last day events. In each teaching, God is the architect, who in wisdom, grace and infinite love, is restoring a relationship with humanity that will last for eternity.

13.See also the remarks below about similar groups in the United States.

14.See, for example, Niebuhr (1929:52) and the discussion of other examples in De Villiers (2016:245).

15.The website of the church reveals the conviction that such care has biblical roots: This priority springs from a deeply held belief in service. Throughout the Old Testament, God made provision for the poor and less fortunate living in Israel. In the New Testament, the writings of the apostle Paul show a Christian church that gave willingly and generously to support the needy among them (Dt 15:1-11, 2 Cor 8:8-15) (https://www.adventist.org/en/service/humanitarian-work/). experiences. However, the 20th century ${ }^{16}$ saw a strong reversal in this situation when apocalypticism was regarded as the key to understanding early Christianity. This turn was exemplified by the famous dictum of Ernst Käsemann (1960), who, for example, claimed that apocalypticism was the mother of all Christian theology. Käsemann's remark is not so unusual. Prominent systematic theologians like Pannenberg, Moltmann, Sauter and Bloch and many others were the early researchers who argued along similar lines. ${ }^{17}$

In summary, then, the Branch Davidians had a religious commitment and beliefs that display commonalities and have links with the widely established Protestant Christianity in the United States. They, too, were committed to their religion, sought spiritual practices to grow deeper into their faith as was the case in many other traditions, held the bible in the highest regard and were, ultimately, seeking the will of God for their spiritual life and journey. Like many others, they too had their liturgical practices and services, with bible readings, sermons, hymns and prayers. ${ }^{18}$ In this sense, one could even state that they did not represent an entirely new religion. ${ }^{19}$ This also confirms that they cannot be regarded simply and in a facile manner as a dangerous, obscene sect or cult.

Their religious commitment, desire to study the bible, the sensitivity about the negative attitudes to their community, the sense of belonging to a tradition and the desire to live in peace are reflected in remarks of Thibodeau (1999), a survivor of the invasion, who noted:

We have no formal name for our community. If anyone asks, we just say we're students of the Bible ... We are not, as the FBI and the fevered media claim, a crazy 'sect' or 'cult' led by a man they've dubbed the 'sinful Messiah'; rather we are a continuity in more than a half century of serious religious faith. We've long lived in peace with our neighbors. Above all, we have never threatened anyone. (p. vii)

And then, he also adds this response to the violent siege and offers an almost mystical remark about spiritual practices and commitment that some pursued:

I'm no religious fanatic, just a dreamer looking for answers in a place called Waco. The two years I've been here have been tough, but they've tempered my body and my spirit. I've quietened my

16.This was partially not only the result of new finds, like the Nag Hammadi texts (1945), the Dead Sea Scrolls (1947), but also because of the publication of collections of apocalyptic texts by Kautzsch (1900) and Charles (1913), to name only the two best-known examples from the early 20 th century.

17.Bloch, for example, regarded Christianity as a revolutionary movement in line with Jesus as an apocalyptic revolutionary.

18.Boyer (1993) writes: His rambling hour-long sermon broadcast early in the siege (as part of a deal he struck with the negotiators) was in important respects indistinguishable in tone and content from the presentations of other apocalyptic preachers who now crowd the airwaves. From Michigan comes the durable Jack Van Impe, known as the 'Walking Bible'; from Tulsa, Oral Roberts. Charles Taylor's 'Today in Bible Prophecy' radio show based in Huntington Beach, California, airs on more than twenty stations nationwide and globally via the Spacenet, SATCOM and Galaxy communications satellites. David Webber's "Southwest Radio Church' of Oklahoma City is heard five days a week on 130 stations. Pat Robertson's Christian Broadcasting Network (CBN), which fully believes in the apocalyptic Scriptures, Broadcasting Network (CBN), which fully believes in the apocalyptic Scriptures, serves some 3000 cable T.V. systems. Another fundamentalist outlet, Trinity Broadcasting Network (TBN), brings prophecy-oriented shows to homes across the late-breaking developments.

19.Gallagher (2014) argues that they intended not to form a new religion, but in reality did become a new religion. 
life, reduced my needs, made great leaps in my heart and mind. Being in Mount Carmel has given me a rare inner surety. Put simply, this hard place has made a man of me. Is that a reason to kill me? (p. vii).

All these remarks bring into focus the attitude and prejudices that determined the siege and its violent outcomes. At an early stage, some observers pointed out that the onslaught of the authorities on the compound was extreme. It turned out that their suspicions of illegal arms were unfounded. No illegal weapons were found. The group was, furthermore, willing to negotiate to bring an end to the siege and to work towards finding a solution. But ultimately, the suspicions and contempt blinded the authorities and spurred them on to their violent response to the violence of the siege.

\section{Social standing}

This spiritual nature of the Branch Davidians can be further illuminated by information about the standing and character of the group members. An interesting glimpse into their integrity is provided by their response to the offer of the authorities to give them supplies in exchange for letting their children leave the compound. Transcripts of the negotiations reveal that they refused this offer because they did not regard their family as commodities that can be used as bargaining chips to obtain food for themselves. Also illuminating is their response to the deception of the FBI that sent children that were released from the compound to foster homes instead of family members, as was agreed. The FBI, as Bianchi (2005) writes:

sent in video tapes showing the released children to reassure the Davidians that the children were being treated well. These tapes further upset the parents because the children were shown eating candy, drinking soda, both of which were forbidden by Davidian dietary code, and behaving rowdily, which went against how the children were raised. (p. 47)

For them, their position was a matter of their deep religious convictions and beliefs. This information gives an indication of their parental concerns and educational ideals, which reflect mainstream values.

This remark ties in with a matter that often has also been an issue in terms of apocalyptic movements. Apocalyptic groups are, as was also the case with the Davidians, often regarded as naïve, susceptible, backward and unintelligent. ${ }^{20}$ Other than what was alleged at that time, members of the group were, in the words of Tabor, professor of Religious Studies at the University of North Carolina, 'intelligent, educated, self-aware, rational, and biblically committed Christians' ${ }^{21}$ He refers to Wayne Martin who was a member of the group and who was a Harvard Law School graduate. Thibodeau (1999) writes:

So many of the Davidians have been demonized by the media ...

I felt it my duty to tell the true story of a group of people who

20.It has been a long-standing conviction that apocalyptic groups are socially disadvantaged people (cf. De Villiers 2016).

21.Tabor, Philip Arnold and Dick DeGuerin tried to mediate between the authorities and the Davidians to bring an end to the siege. He co-authored a book that relates his experiences with the title Why Waco: Cults and the Battle for Religious Freedom in America. See https://jamestabor.com/april-19-1993-waco-branch-davidiantragedy-going-on-25-years/. were trying to live according to their religious beliefs and the teachings of a man they all considered divinely inspired. (p. 20)

The general attitude of the group supports the statement that the Davidians cannot be regarded as socially disadvantaged groups or mentally disturbed, backward people under the influence of a deranged leader.

\section{Spiritual practices}

The religious interest of the Davidians was not merely a matter of gaining intellectual knowledge. Their quest for understanding affected them existentially. It was also an approach that had a comprehensive, practical outcome, that is, not only spiritual but also social and political. They spent incredibly long times studying the bible and listening to long sermons and praying. Other spiritual practices included worship services, hymns and taking communion. ${ }^{22}$ They sought to avoid certain sinful habits, including dancing, drinking and smoking (Doyle 2012:97). In addition, they chose a communal lifestyle, sharing accommodation, with men separated from the women and children in separate quarters.

\section{Studying Scripture}

The extensive study of Scripture by the Branch Davidians cannot be understood without taking into consideration their Adventist traditions. On its website, the Adventist church lists 28 beliefs, but frames this list with the following remark:

Seventh-day Adventists accept the Bible as the only source of our beliefs. We consider our movement to be the result of the Protestant conviction Sola Scriptura - the Bible as the only standard of faith and practice for Christians. (https://www. adventist.org/en)/)

The church also offers on this website a description of their spirituality, which included four aspects, namely, Sabbath, bible study, prayer and prophecy. Among these, however, the bible has primary place, not only in terms of beliefs but also as a spiritual practice.

Like in many Protestant traditions, the Branch Davidians refer to their reading of the bible as 'bible study'. ${ }^{23}$ It implies a close, careful investigation of biblical texts. When one reads Koresh's publication (1993) on the opening of the seven seals, it is immediately clear how intensively he busied himself with biblical texts. He quotes many texts from different parts of the bible and let them interact with each other in a creative manner. Bianchi (2005:48) notes how the FBI often in press conferences referred to Koresh's and Schneider's biblical references as 'Bible babble'. And yet, a closer look reveals that his reading of the bible is similar to many other interpreters from the Adventist tradition and from many other charismatic or

22.Gladwell (2014) refers to Docherty who uses Max Weber's typology to describe the Davidians. They were 'value-rational' - that is to say, their rationality was organised around values, not goals. A value-rational person would accept his 14-year-old daughter's polygamous marriage if he was convinced that it was in fulfilment of biblical prophecy.

23.Doyle (2012:9), who reflected on his own role in the group, refers to Koresh who started out with a group of people studying, studying, studying, and learning, learning, learning - but he was frustrated because some of us were still so ignorant on certain issues'. 
Pentecostal contexts. ${ }^{24}$ It is, in fact, ironic that their use of the bible often was similar to that of those who opposed and vilified them.

Their extensive study of the bible assumed that the bible has direct relevance for their own times. They sought guidance of their spiritual journey in the bible as a living word that addressed their needs and questions..$^{25}$ In line with this, they also read the bible as a book with a timeless character. They did not entertain the established notion of mainstream biblical scholars that the bible contains 66 different texts by various authors in terms of specific contexts and, as a consequence, that these books could refer to various, even contradictory issues and have multifaceted meaning. They disdained academic study of the bible. ${ }^{26}$ They simply combined pronouncements in Daniel and Revelation as if they form a coherent whole and comprise one book with one message. Thus, Doyle (2012) observes:

The more David studied with us, the more we began to see that the Bible is not a bunch of different subjects and chapters. $\mathrm{He}$ taught that there were no chapters and verses in the ancient manuscripts. The translators were the ones who added the chapter divisions and numbered the verses. (p. 75)

In his discussion of the seven seals of Revelation, Koresh, for example, interpreted the first seal as a fulfilment of Psalm 45: 'How can any man deny that the first seal is a preview into the event spoken of by the 45th Psalm' (Koresh 1993:8-9). For Revelation 19, he uses verses from Isaiah 33:17, 55:3-4, 61:810; Jeremiah 23:5-8, 18-20; 33:14-16; Ezekiel 37:24-25; Daniel 12:1; Hosea 2:14-23; Joel 2:15-16; Amos 9:11, 14,15; and Obadiah 21. Koresh, for example, regarded Isaiah 40-66 as one vision that had a literal meaning, 'not divided up into little subjects. Most of it describes prophesied consecutive events'. Other than in biblical studies as a discipline, they displayed limited interest in the meaning of biblical texts in original situation and communication setting. ${ }^{27}$ Inherent in many of their pronouncements is a disdain for academic study of the bible which required from interpreters to understand the text historically and contextually. ${ }^{28}$

The special character of their reading of Scripture presents an ironic picture. They considered the end events that are described in biblical texts as literal predictions that would take place one after the other in the future. And yet, their readings imply that biblical passages are not to be taken on face value. They contain hidden mysteries that can only be decoded through careful study and interpretation by someone who has the gifts of prophecy and can unlock the realities, events and people who are involved.

24. Koresh (1993) notes that: "Although his interpretation is unique in its specific application and reference, it is similar in method and style to other well known exegetes such as Isaac Newton, Joseph Smith, Ellen G. White, J.N. Darby, C. I. Schofield, or Hal Lindsey' (p. 3).

25.Doyle (2012:75) remarks that Koresh 'made scripture come alive. He showed that all of the prophets in the Bible were writing more for our day than for their own time'.

26.Koresh (1993) wrote: 'In my work to unfold this mystery to you I will not use great techniques of scholarly display nor indepth reasonings of philosophy, no sophisticated, congenial language shall be used, just simple talk and reason' (p. 3).

27 See footnote 25

28 See footnote 26
This consistent fundamentalist approach to the bible reflects a growing trend among certain groups in the contemporary religious discourse. Barkun (1996:2) noted that Protestant fundamentalists 'are almost universally millenarian in their anticipation of the imminent end of history'. Except that this way of reading the bible is compromised, it also has serious consequences. Fundamentalism reflects a dangerous binary mindset that divides society into two camps and feeds on a deadly struggle between good and evil. Fundamentalists posit an unbridgeable gap between themselves as the righteous, knowledgeable, chosen few and their opponents, the status quo and the mainstream religious setting, who, in their eyes, are contaminated by evil, sin and impurity and who have an ungodly, corrupt agenda. The binary narrative is so problematic because it thrives on exclusion, vilification and violence: opponents are depicted as ruthless killers who as a group persecute the elect of God and who must be resisted with might. It cultivates a self-righteousness that is supported by a craving for martyrdom for a divine cause and an eagerness to participate in the ultimate war against evil. There is little openness for dialogue, for conceding the tentativeness of an own belief or position, thus promoting the same intolerance that is being projected on their opponents.

Such a binary, agonistic mindset is also a problem because millenarian groups see themselves 'as a potent political actor, with the capacity to shape the public agenda on issues that range from abortion to policy in the Middle East' (Barkun (1996:2). They pursue their political activity with great determination and even with violence, as attacks on those who dissent from their views, indicate. The Branch Davidians' criticism of society and their political reading of the future exemplifies this point.

\section{Eschatological focus}

As the history of this Protestant tradition and the previous remarks show, the Davidian identity is determined first and foremost by an eschatological reading of the bible. ${ }^{29}$ Although many Protestant traditions would read the bible primarily from an eschatological perspective as the fulfilment of prophecy in and through Christ, the Branch Davidians, like the Adventists, understood this as a futurist eschatology. The bible was about the end time, and then, particularly about the destruction of the existing world and the coming of God's final kingdom. The bible thus was seen as containing predictions about the last days when the world would be destroyed (Doyle 2012:98).

This emphasis on an eschatological reading of the bible is illustrated by the seminal role they allocated to the book of Revelation in their theology:

David taught that all the books of the Bible meet and end in The Revelation of Jesus Christ to John, the last book in the Christian Bible. The book of Revelation is like the summary, the wrap-up of all the Bible's prophecies (Doyle 2012:76; cf. also Koresh 1993:7).

29. Boyer (1993) refers to the prominence of certain key images in apocalyptic texts that characterise their interpretation of the bible, such as Nebuchadnezzar's Dream in Daniel and, in Revelation, the Whore of Babylon and the Beast from the Sea. 
Two aspects are important here: first of all, the bible was read literally as containing a message about future events that would take place one after the other. The prophets were read as descriptions of consecutive events. There is a linear development in what will happen:

David taught that Revelation is being shown to John in a vision in which he sees a book sealed with Seven Seals being opened, and everything you see from that point on is pretty consecutive as far as the order in which it will be fulfilled. (Doyle 2012:76)

Secondly, they regarded the coming of the end as imminent and something that they themselves would experience: The Davidians were convinced that they lived in the time of the fifth seal, just before the end that would come with the appearance of the Antichrist. This was a time in which Revelation 6:10 was being fulfilled. As the saints, they were waiting a little longer and persevered in the suffering and persecution to which they were subjected.

\section{The prophet}

The Branch Davidians, like most millenarian movements, sought to discover the will of God for humanity in the bible. Their reading was, however, guided by their leaders. ${ }^{30}$ To the Branch Davidians, Koresh was the one who discerned the divine will. They did, however, also study prophecies by earlier leaders of the Davidian Adventists. Doyle (2012:75-76) noted how he analysed the insights of Lois Roden, the wife of the founder of the Branch Davidians and the second president of the group, who claimed that her study of Revelation 18 led to a vision that the Holy Spirit was feminine. ${ }^{31}$ He (2012:8990) also mentions the work of Houteff, the president of the Davidian Adventists, who wrote in his Leviticus of the Davidian Seventh-day Adventists about the coming Kingdom of David. The Branch Davidians, who split from the Davidian Adventists, ultimately accepted David Koresh as the only authority to interpret biblical prophecy.

At several of its stages of development, the Davidians had leaders who claimed extraordinary authority, namely, that they were Revelation's Lamb of God. ${ }^{32}$ Koresh, for example, told them that he was taken up to heaven where the meaning of the seven seals of the scroll described in Revelation 4-6 about the end was revealed to him. He explained his divinely appointed mission in terms of Revelation 1 . He reads the phrase that John sees a revelation of Christ as meaning a revelation 'by Jesus Christ or somebody called Christ' (Doyle 2012):

David made a big point that he saw himself as the Lamb opening the book to us. He did not open it to everyone else. He opened it to us. I believe it was opened to him and he passed it on to us. (p. 76)

Although the claim to have exceptional authority did not mean that he thought of himself as divine, he intensified his

30.See Faubion (2006:189) on Roden who accepted the authority of five Adventist leaders. William Miller, Ellen White, Victor Houteff, and Ben and Lois Roden.

31.See also the discussion of Doyle (2012:77)

32.Faubion (2006:19) refers to Roden who speaks of Houteff (the founder of the Davidians) as the Lamb of Revelation who opened the seals. own authority and the group's solidarity in biblical terms. ${ }^{33}$ His followers found his exposition of Scripture and his leadership so compelling that they willingly obeyed his instructions and accepted his sometimes harsh punishment of members for any dissent. It helped that he could address them with extremely long sermons.

Koresh is an example of charismatic leaders in millenarian movements who claimed the prophetic gift of deciphering the future. Prophecy was more than merely reflecting on the will of God. It was about revealing the programme of events for the end time that would bring about the destruction of the world and the inauguration of the new world in its place. A most illuminating incident that explains the eschatological focus of the Davidians happened during the siege. Whilst they were held in dire circumstances, Koresh insisted that he would only surrender after he could write down an explanation of the seven seals of Revelation which, according to Revelation 4-5, was only known to the Lamb. He thus claimed that the prophecy about the final end was being made known by him. ${ }^{34}$ The crucial point here was that his prophetic activity was vital for his followers. Because he was the Lamb of God who could explain the will of God as presented in the seven seals of Revelation, his revelation was not merely one of many interpretations. It had exceptional authority and could only be ignored at one's own peril.

\section{Family life and wives}

The full implications of the previous remarks about Koresh authority can be discerned from Koresh's moral position. His followers were not only willing to accept his prophecies but also his highly controversial family and social rulings. It has been mentioned previously that he had sexual relationships with 20 odd women, who had children with him and who were in some cases also under age. Koresh was a sexual predator and someone who had little respect for the traditional view of the sanctity of marriage, as is clear from the fact that he separated women from their husbands and had sexual relationships with them. In a bizarre manner, he offered to their husbands and to his flock a biblical foundation for his aberrant behaviour, explaining that the women were his 'spiritual wives'. He provided them with biblical reasons for this arrangement. He referred to Psalm 45 that speaks of a great king, anointed by God, who marries many princesses and creates a mighty dynasty that will one day command the world. Koresh argued that his 'spiritual wives' had been taken in fulfilment of that prophecy. ${ }^{35}$ Once again the bible is used to spiritualise a practice that he knew would normally be considered as illegitimate and wrong. Of special importance is

33.See Koresh (1993) in which Tabor and Arnold claim that Koresh did not see himself as Christ or as God.

34.For a discussion of the charismatic authority of a leader in terms of Weber's treatment, see Faubion (2006:193-194). His list of hallmarks of such a leader includes being unroutinised, unthrifty, removed from everyday life, absolutist, indifferent to precedent and unstable, at odds with custom, convention and order. This analysis resonates with the activities of the Davidians.

35. For the role of sex in the Branch Davidians and Koresh's notion of spiritual wives, see Bradley (2014, web page) who refers to a remark by Koresh: These children that I have are for a reason, and unless we really have the ear and the eyes to open ourselves up and understand the prophecies in a lot of the Seven Seals the ourselves up and understand the proph
explanation would seem almost foolish. 
that Koresh had the support of the women in question and, in some cases, and, more bizarrely, of the women's spouses. They were not brainwashed women, but were, as was noted above, convinced by Koresh's compelling bible exposition that they were sharing foundational values in the bible. Once again, their faith was determined by a basic fundamentalist hermeneutics with its literalist readings of Revelation.

Most outsiders would regard this motivation of his sexual practice as a twisted use of the bible, especially when one considers it from the perspective of contemporary biblical exegesis. It will also be criticised as contrary to traditional monogamous views of marriage and sexual relationships, even if his practice had the support of the women in question and, in some cases, and, more bizarrely, of the women's spouses. It does, however, reflect a key characteristic of millennial movements that did not hesitate to challenge ${ }^{36}$ the convictions, conventions and culture of the status quo. ${ }^{37}$

\section{Alienation}

The spirituality of millenarian movements finds special meaning within the social context in which they function. In some cases, they reflect the religious desire of people to deepen their faith and to know more about God. This desire is also to be seen in the spiritual quest of Davidians to learn more about Scripture. Often, though, the millenarian movements are closely linked with a pessimistic outlook on the world. It then is the result of the alienation and anxiety that people feel in liminal situations and times of change. This anxiety is closely linked with social and political conditions. In the earliest phases, millennial groups appropriated the message of Revelation to cope with Roman oppression that they experienced as persecution. The eschatological pronouncements of Victorinus, for example, who was martyred in 303, reflect his experiences during the persecution of Emperor Diocletian. He interpreted his situation in terms of Revelation when he described Rome as the infamous Babylon in Revelation 17-18. To him, Revelation was a source of inspiration, consoling its readers with hope that their present situation is only temporary, just a precursor to the final bliss that awaits the faithful at the end of time. At the same time, the book illuminated the true identity of the opponents. It provided a divine perspective on their situation and the language to express the depravity of the opponents.

Like with many other millenarian groups, the Davidians also found relief and meaning in Revelation. Also they experienced deep alienation. They used biblical language to express their conviction that they were persecuted by the state and the church, ${ }^{38}$ explaining that they were being drawn into a final

36. Koresh, according to Doyle (2012), confidently speaks about the divine Judgement as the ultimate legitimation of his position. He notes how God will ask: You killed this man because he had more than one wife. You killed this man because he had a lot of kids, you killed this man because he had guns, or you killed him because he a lot of kids, you killed this man because he had guns, or you killed him because he follows this strange sentence, 'David said: Fine, and where are you at? What has religion done for you?'

37.The polygamous marriages of Mormons come to mind as an example.

38.See Faubion (2006:190) for Roden's criticism of the corrupt Seventh-Day Adventist Church. battle with the forces of Babylon. Other biblical texts were also used to explain events. During the siege, Steve Schneider, a member of the group, called a family member to look up the book of Nahum that explains what was happening to them. The prophecy in that book illuminates the struggle that was taking place as persecution of the chosen people by the state:

The chariots of flaming torches are tanks. That's what Nahum saw in the final days, they've surrounded us. It's the first time in the history of the United States that the government is using tanks against its own people. (Bianchi 2005:50) ${ }^{39}$

The alienation is also evident in Koresh's remarks about the second beast with the two horns in Revelation 13:11 that presents itself as Christian, but is of the devil. Doyle (2012:92) notes what he observed: 'The United States plays the role of the two-horned beast, two horns referring to the two dominant political parties. The two-horned beast thinks to persecute God's people.' The Old Testament 'Assyrian' is primarily the United Nations, but it needs to be remembered, he added, that the United States leads the United Nations. Later on he notes (p. 96) that the second beast that wants to make a copy of the first beast, refers to the new world order that entails nations coming together to persecute God's people. People will be forced to join this order. Those who refuse will not be able to participate in the economy. That is why living in a commune like Mount Carmel and 'not shopping at Walmart' makes sense (p. 97). This alienation is strong, even overpowering: the small, brave and committed group stands on its own, facing extraordinary dangerous and powerful opponents.

\section{Conclusion}

Recent research suggested that one can learn even from failed predictions of the world's end about the 'profound hopes and disappointments ... that stir the soul and produce lasting and powerful religions of salvation'. Not only the Adventist tradition, but also the Branch Davidians would have had their profound hopes and disappointments. Contemporary readers who read Revelation, and also the writings of the Branch Davidians from a perspective of understanding and empathy, can recognise these hopes and disappointments as 'the very stuff of religious history' (Landes 2003:10). It is sad that the anxieties and alienation of a committed group of people like the Davidians were confirmed and even intensified by those who misunderstood them. The events at Waco are an example of the destructive consequences of intolerance and prejudices. It says more about the spirituality of those, that hold others that differ from them, in contempt. However, one may disagree with others and their practices; this episode reminds one not only of the need for tolerance and understanding, but also for mercy and compassion, which are key themes in spirituality: it is truly a divine gift to recognise, acknowledge and respect the spiritual gifts of people who desire to find God, how frail

39. Boyer (1993) indicated that also Koresh should be understood in terms of his time and place in which groups felt alienated and criticised the establishment structures and institutions. It was a time that reveals an increasing hostility toward the US federal government. 
and brittle they may be. One should strive to recognise the deepest desires and the need for consolation and comfort that live in the hearts and minds of even one's worst enemies. At the same time, one cannot but notice, and lament, the hard, darker parts of the spiritual quest of those with utopian visions. These visions may comfort and console, but they can also bring those who harbour them to vilify, to exclude with hatred, to be blind to the corrupt practices of leaders and to expose the naïve to dangerous risks. This criticism is done not to judge and reject, but to remind one that, as in the book of Revelation, evil appears to us often in the guise of the good.

\section{Acknowledgements Competing interests}

The author declares that he has no financial or personal relationships which may have inappropriately influenced him in writing this article.

\section{References}

Abrams, M.H., 1984, 'Apocalypse: Theme and variations,' in C.A. Patrides \& J.A. Wittreich (eds.), The apocalypse in English Renaissance thought and literature: Patterns, antecedents, and repercussions, pp. 342-367, Manchester University Press, Manchester.

Barkun, M., 1996, 'Introduction: Understanding millennialism', in M. Barkun (ed.), Millennialism and violence, Frank Cass, London.

Bianchi, J., 2005, 'They fought the law and the law kept winning: Fifty-one days at Mount Carmel', MA thesis, University of North Carolina Wilmington.

Boyer, P., 1993, 'A brief history of the end of time. The American roots of the Branch Davidians', The New Republic, May 17, viewed 02 July 2018, from https:// newrepublic.com/article/112972/branch-davidians-and-american-millennialism

Bradley, M.S., 2014, 'Gender among the Branch Davidians', in H. Bogdan \& J.R. Lewis (eds.), Sexuality and new religious movements, pp. 29-58, Palgrave Macmillan, New York.

Charles, R.H. (ed.), 1913, The apocrypha and pseudepigrapha of the Old Testament in English, Clarendon Press, Oxford.

Cohn, N., 1970, The pursuit of the millennium: Revolutionary millenarianism and mystical anarchists of the Middle Ages, Paladin, London.
De Villiers, P.G.R., 2016, 'Apocalyptic groups and socially disadvantaged contexts'. Acta Theologica 23, 238-262. https://doi.org/10.4314/actat.v23i1S.12

De Villiers, P.G.R., 2017, 'Reading the Book of Revelation politically', SJT 3(2), 339-360.

Dick, E.F., 1986, 'The Millerite movement 1830-1845', in G. Land (ed.), Adventism in America: A history, pp. 1-35, Eerdmans, Grand Rapids, MI.

Doyle, C., 2012, A journey to Waco: Autobiography of a Branch Davidian, Rowman \& Littlefield, Plymouth.

Faubion, J.D., 2006, 'Paranomics: On the semiotics of sacral action', in M. Engelke \& M. Tomlinson (eds.), The limits of meaning. Case stuies in the anthropology of Christianity, pp. 189-210, Berghahn Books, New York.

Gallagher, E., 2014, Writing scripture in new religious movements: New bibles and new revelations, Palgrave Macmillan, New York.

Gladwell, M., 2014, 'Sacred and Profane. How not to negotiate with believers', The New Yorker, 31 March, viewed 01 March 2018, from https://www.newyorker. com/magazine/2014/03/31/sacred-and-profane-4

Jewett, R., 1979, Jesus against the rapture. Seven unexpected prophecies, The Westminster Press, Philadelphia, PA.

Kautzsch, E. (ed.), 1900, Die Apokryphen und Pseudepigraphen des Alten Testaments, Mohr, Tübingen.

Käsemann, E., 1960, 'Die Anfänge christlicher Theologie', ZThK 57, 162-185.

Kaminsky, H., 2004, A history of the Hussite revolution, Wipf and Stock, Eugene, OR.

Koresh, D., 1993, The decoded message of the seven seals of the Book of Revelation, viewed n.d., from https://www.google.com/search?client=safari\&rls=en\&q=the+ decoded+message+of+the+seals+koresh\&ie=UTF-8\&oe=UTF-8

Landes, R., 2003, 'Introduction: The terribles Espoirs of 1000 and the tacit fears of 2000', in R.A. Landes, A.C. Gow \& D.C. Van Meter (eds.), The apocalyptic year 1000: Religious expectation and social change, 950-1050, pp. 3-16, Oxford 1000: Religious expectation
University Press, Oxford.

Lawrence, D.H., [1932] 2002, Apocalypse, Martin Secker, London.

Newport, K.G.C., 2017, Florence Houteff. Word religions and spirituality, viewed 03 March 2018, from https://wrldrels.org/2017/04/15/florence-houteff/

Pedrotti, A.M., 2017, 'On trial: The branch Davidians of Waco, Texas 1987-1993', MA thesis, Wright State University. Browse all Theses and Dissertations, 1733, viewed from https://corescholar.libraries.wright.edu/etd_all/1733

Rapoport, D.C., 1996, 'Preface', in M. Barkun (ed.), Millennialism and violence, Frank Cass London, Portland, OR.

Roman, R.L., 1996, 'Christian themes: Mainstream traditions and millenarian violence', in M. Barkun (ed.), Millennialism and violence, pp. 52-82, Frank Cass London, Portland, OR.

Rossing, B.R., 2004, The rapture exposed: The message of hope in the Book of Revelation, Westview Press, Boulder, CO.

Tabor, J.A. \& Gallagher, E. (eds.), 1995, Why Waco: Cults and the battle for religious freedom in America, University of California Press, Berkeley, CA.

Thibodeau, D., 1999, A place called Waco: A Survivor's story, Public Affairs, New York.

Watson, W.C., 2015, Dispensationalism before Darby: Seventeenth-Century and Eighteenth-Century English Apocalypticism, Lampion Press, Silverton, OR. 